\title{
POPULATION BIOLOGY OF Parides anchises nephalion (PAPILIONIDAE) IN A COASTAL SITE IN SOUTHEAST BRAZIL
}

\author{
FREITAS, A. V. L. ${ }^{1}$ and RAMOS, R. R. ${ }^{2}$ \\ ${ }^{1}$ Museu de História Natural and Departamento de Zoologia, Instituto de Biologia, Universidade Estadual de \\ Campinas, C. P. 6109, CEP 13083-970, Campinas, SP, Brazil \\ ${ }^{2}$ Programa de Pós-graduação em Ecologia, Instituto de Biologia, Universidade Estadual de Campinas, C. P. 6109, \\ CEP 13083-970, Campinas, SP, Brazil \\ Correspondence to: André Victor Lucci Freitas, Universidade Estadual de Campinas, Instituto de Biologia, \\ Departamento de Zoologia, C. P. 6109, CEP 13083-970, Campinas, SP, Brazil, e-mail: baku@atribuna.com.br \\ Received May 3, 2000 - Accepted June 21, 2000 - Distributed November 30, 2001
}

(With 3 figures)

\begin{abstract}
A population of Parides anchises nephalion was studied during seven months in SE Brazil. The population size was about 10-20 individuals (with theoretic maximum near 60 individuals), with small variations in some months. Sex ratio was male biased, with males dominating in all months. The age structure was not stable, with an increase in new individuals before the population peak in December. The residence time was $14.1 \pm 8.2$ days for males and $9.0 \pm 3.6$ to females, with the maximum registered of 30 days. Males can travel distances of up to $400 \mathrm{~m}$, but most individuals were always recaptured in the same site. The mean forewing length was greater in females. The population features agree with those found in other species of Parides in other neotropical sites.
\end{abstract}

Key words: Papilionidae, Parides, population biology, Troidini, mark-realease-recapture.

\section{RESUMO}

Biologia populacional de Parides anchises nephalion (Papilionidae) em uma área litorânea no Sudeste do Brasil

Uma população de Parides anchises nephalion foi estudada ao longo de sete meses no Sudeste do Brasil. O tamanho populacional variou em torno de 10-20 indivíduos (com um máximo teórico próximo a 60 indivíduos), com pequenas variações em alguns meses. A razão sexual foi desviada para excesso de machos, com estes sendo dominantes em todos os meses. A estrutura etária não foi estável, com um aumento dos indivíduos novos antes do pico populacional em dezembro. $\mathrm{O}$ tempo de residência foi de 14,1 $\pm 8,2$ dias para machos e 9,0 $\pm 3,6$ dias para fêmeas, com um máximo registrado de 30 dias. Os machos podem se deslocar por distâncias superiores a $400 \mathrm{~m}$, entretanto, a maioria dos indivíduos foi recapturada sempre no mesmo local. O comprimento médio das asas anteriores foi maior nas fêmeas. As características da população estão de acordo com aquelas descritas para outras espécies de Parides em outros sítios Neotropicais.

Palavras-chave: Papilionidae, Parides, biologia populacional, Troidini, marcação-recaptura.

\section{INTRODUCTION}

Population studies of butterflies (using markrelease-capture method) have been considered an important step in understanding their ecology and behavior, usually revealing many features with few months of work (Ehrlich, 1984; Tyler et al., 1994). In the tropics, most studies have been done with forest species (Schappert \& Shore, 1998), especially Heliconiini (see references in Ramos \& Freitas 1999). However, many studies of tropical butterflies were carried out with species of 
Ithomiinae (Drummond-III, 1976; Haber, 1978; Young \& Moffet, 1979; Vasconcellos-Neto, 1980; Trigo, 1988; Freitas, 1993, 1996; Pinto \& Motta, 1998) and Papilionidae (Cook et al., 1971; BrownJr. et al., 1981, 1994; Morais \& Brown-Jr., 1992; Tyler et al., 1994).

Species of Papilionidae are considered easy to study; they are strongly attracted to flower patches or wet sand, are of large size, and are easy to mark without causing trauma.

However, good long-term population studies on Papilionidae are very few, both in North American and especially neotropical species (Tyler et al., 1994), making any additional study on this group an important source of information future work. The present paper describes the population features of Parides anchises nephalion (Godart, 1819), a papilionid butterfly common in several kinds of forests in SE Brazil (Tyler et al., 1994), being especially common in habitats with a lowto-medium level of disturbance along rivers, in clearings, and along forest edges (Brown-Jr. et al., 1981; Brown-Jr., 1992; Morais \& BrownJr., 1992; Tyler et al.; 1994).

\section{STUDY SITES AND METHODS}

A mark-release-recapture (MRR) study was carried out in Morro do Voturuá $\left(46^{\circ} 22^{\prime} \mathrm{W}, 23^{\circ}\right.$ $57^{\prime}$ S), in the city of São Vicente. The site was originally covered with lowland subtropical rainforest (Ururahy et al., 1987). The annual rainfall reaches $2500 \mathrm{~mm}$ and the average annual temperature is $21{ }^{\circ} \mathrm{C}$ (Setzer, 1949; Prodesan, 1969; Nimer, 1972 ), with the mean in the coldest month of $18.2^{\circ} \mathrm{C}$ and in the warmest month of $25.3^{\circ} \mathrm{C}$ (Santos, 1965) (Fig. 1 - methods following Santos 1965, and Walter, 1985). Most of the area is covered by secondary forest on low hills (100-200 m elevation), and the study was conducted on a trail about $700 \mathrm{~m}$ long passing through anthropic areas and entering the forest (details of the area are in Ramos \& Freitas, 1999). Mark-release-recapture studies were made during 7 months, from 5 August 1996 to 17 February 1997, totaling 28 field days (about 4 hours/day). Butterflies were captured with an insect net, individually numbered on the underside of both forewings (in the white central macula) with a black permanent felt-tipped pen, and released.

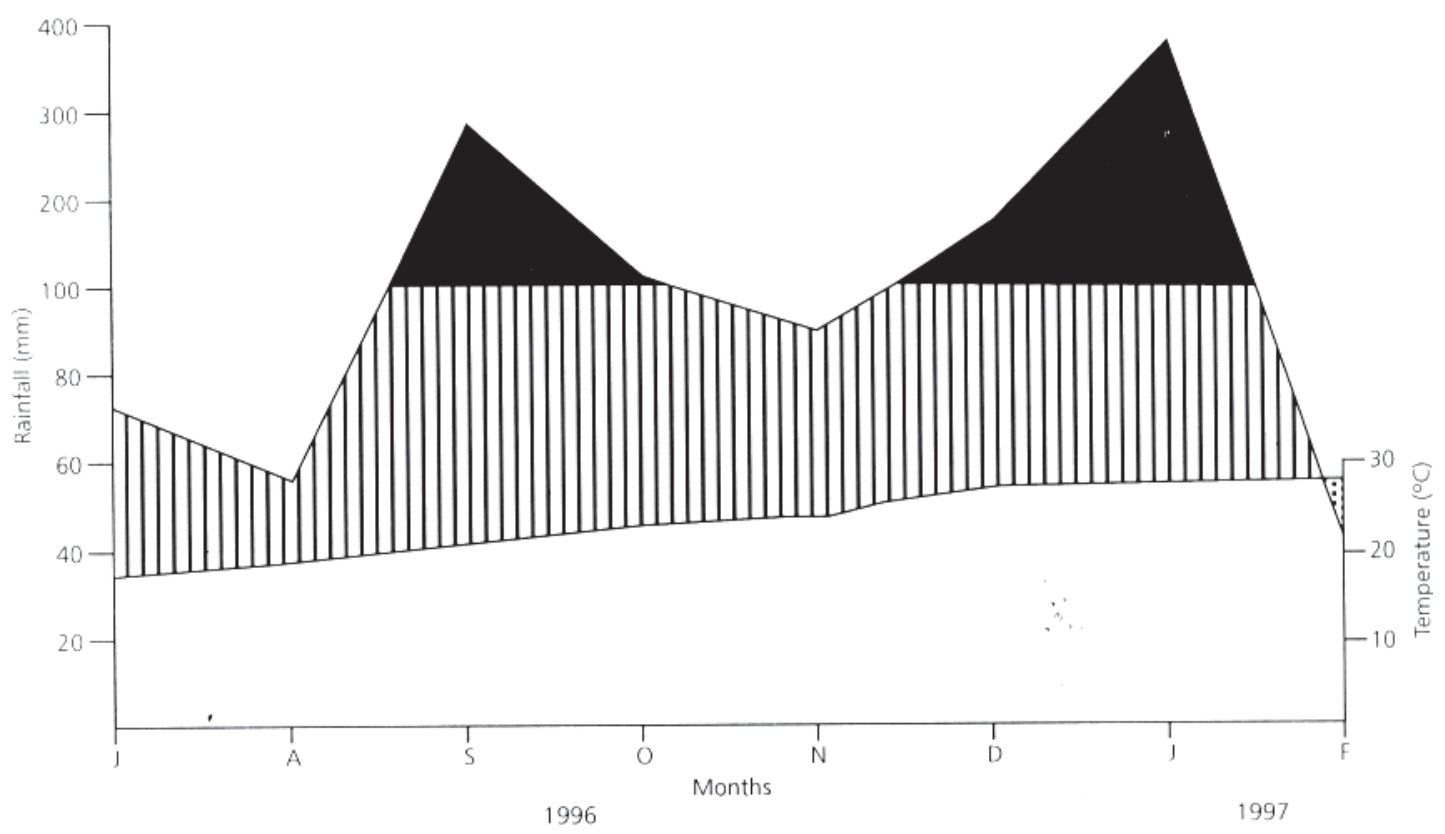

Fig. 1 - Climatic diagram of the São Vicente region during the study period (format following Santos, 1965, and Walter, 1985). Hatched $=$ humid periods; black $=$ superhumid periods; and dotted $=$ dry periods. 
Age (based on wing wear), forewing length (in $\mathrm{mm}$ ), point of capture, sex, and food sources were recorded (Freitas 1993, 1996; Ramos \& Freitas, 1999). The age of individual butterflies was estimated in six categories based on wing wear (Ehrlich \& Davidson, 1960; Brussard \& Ehrlich, 1970; Ehrlich \& Gilbert, 1973). Age structure was calculated as the daily proportion of each category, and grouped into monthly means.

The MRR data were analyzed by LincolnPetersen-Bailey, Jolly-Seber and Manly-Parr methods (Southwood, 1971) for estimating population parameters (software developed by R. B. Francini, UNISANTOS). Only males were analyzed because of the low number of females. Daily results were tabulated as "number of individuals captured per day" (NICD, including marked + recaptured), and "number of individuals present per day" (NIPD). To estimate the NIPD, recaptured individuals were considered to be present in the population on all previous days since the day of first capture (= marked animals at risk).

\section{RESULTS}

Population dynamics: The NICD varied from one to 11 for males $($ mean $=3.75 ; \mathrm{SD}=2.34 ; \mathrm{n}=$ 28 days), and 0 to 7 for females (mean $=1.21 ; \mathrm{SD}=$ $1.75 ; \mathrm{n}=28$ days). The NIPD of males also varied from one to 11 (mean $=4.32 ; \mathrm{SD}=2.84 ; \mathrm{n}=$ 28 days) (Table 1, Fig. 2). The population was stable from August to November, with a small increase in number of individuals in December, 1996, with the number of individuals decreasing in January and
February, 1997 (Fig. 2). The results of population analysis are shown in Table 1 . In general, the three methods showed that population size varies from 10 to 20 males. Considering the maximum values (number estimated plus one standard error), population size could reach values around 40 males, with up to 60 males on some days (Table 1). However, due to the low number of recaptures, these estimations should be considered with caution.

Sex ratio: The sex ratio of individuals captured and marked was male biased (77 males and 31 females marked; $\left.\chi^{2}=19,6 ; \mathrm{P}<0.001\right)$, and near 2.5 males : 1 female. Males dominated in all months, and all the captured individuals were males on October, 1996 and February, 1997 (Fig. 3, Table 2). Males were recaptured from one to four times, but females only once; 18 males $(23.4 \%)$ and three females $(9.7 \%)$ were recaptured at least once.

Age structure: The six initial age categories were grouped into 3: young, including freshly emerged and new; intermediate (the same); and old, including old, very old, and a few tattered (Freitas 1993, 1996; Ramos \& Freitas, 1999). Age structure during the six months was not stable, with an increase in the number of young individuals in September, followed by an increase in the proportion of old individuals in November and December (Fig. 3).

Residence time: The residence time (based on recaptured individuals) varied from one to 30 days for males $($ mean $=14.1$ days; $\mathrm{SD}=8.22 ; \mathrm{n}=18$ ) and from five to 12 days for females $($ mean $=9$ days; $\mathrm{SD}=3.61 ; \mathrm{n}=3$ ), but statistical differences could not be calculated due to the low number of females. Table 3 shows permanence in the population for males.

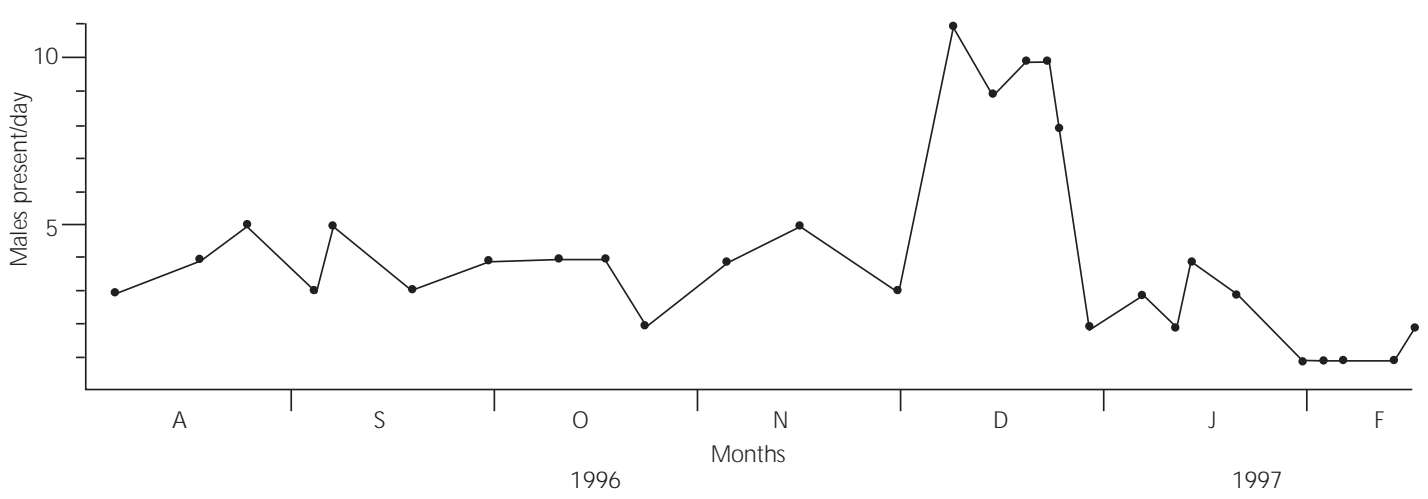

Fig. 2 - Population size (based on the NIPD) of Parides anchises nephalion (males) in Morro do Voturuá, August, 1996 to February, 1997. 

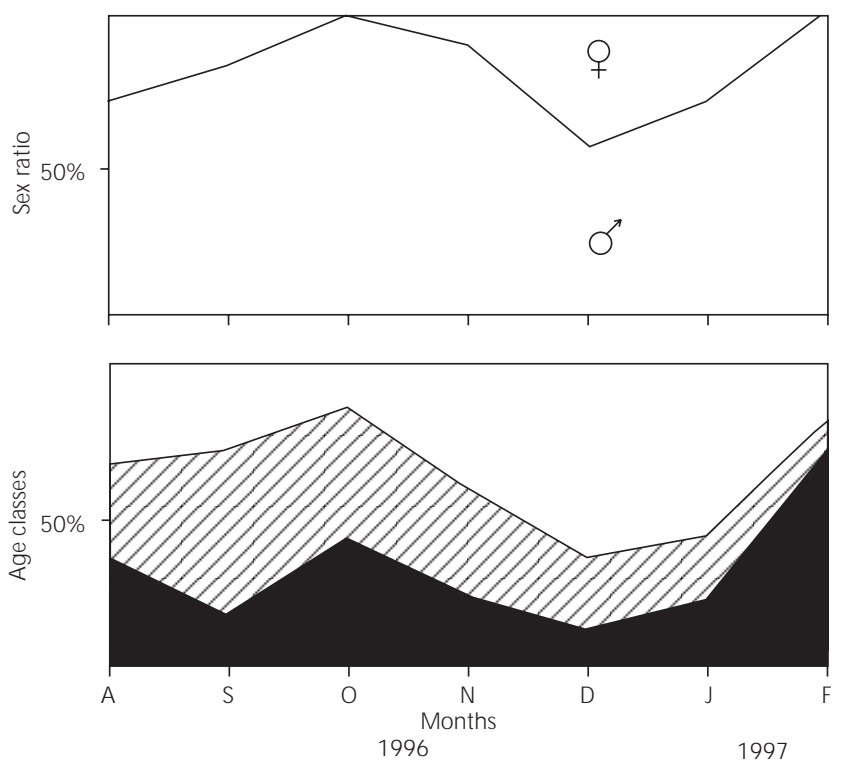

Fig. 3 - Populational parameters of Parides anchises nephalion marked in Morro do Voturuá, August, 1996 to February, 1997. Above, sex ratio (based on monthly recruitment), as percent of males in each month's captures; below, age structure (for males only). Black = young individuals; hatched = intermediate; and white = worn individuals; as \% of each day's captures).

Life expectance of males (following Cook et al., 1967) was calculated as 5.64 days.

Vagility: Only males were analyzed due to the low number of recaptures of females. The maximum distance traveled by an individual was $400 \mathrm{~m}$ in a straight line. In general, most individuals were recaptured at the same site (13 of the 18 recaptured individuals), and 5 individuals were recaptured at a different point $($ mean $=200 \mathrm{~m}, \mathrm{SD}=141.4, \mathrm{n}=5)$.

Wing size: The forewing length ranged from 32 to $51 \mathrm{~mm}$ in males and from 39 to $51 \mathrm{~mm}$ in females. The average forewing length of females (mean $=42.2 \mathrm{~mm}, \mathrm{SD}=3.71, \mathrm{n}=75$ ) was greater than that of males $($ mean $=46.8 \mathrm{~cm}, \mathrm{SD}=2.99$, $\mathrm{n}=31 ; \mathrm{t}=6.12$, df $=104, \mathrm{p}<0.001)$. The variation in mean forewing length of males showed no clear pattern along the study period (Table 2).

Adult natural history and behavior: In the study area Parides anchises nephalion is a common species found in secondary areas, and the adults are commonly found flying in forest, feeding on flowers on forest edges or near the host-plants. Besides $P$. anchises, $P$. agavus was the only additional species in the genus present in the study area, but two additional species, $P$. tros and $P$. zacinthus are present in nearby sites (ont the mountain slopes, and coastal sand forests respectively). Adults began activity around $0800 \mathrm{~h}$, but this could vary within a season according to the weather. They presented low flight (from 0.5 to $2 \mathrm{~m}$ high), but could be observed flying more than five meters high on several occasions. Adults were almost always observed feeding on flowers, with the species most used in this site being Impatiens walleriana Hook.f. (Balsaminaceae) (100 records), an introduced plant species that produces flowers year-round. Additional species observed being used as nectar sources by $P$. anchises nephalion were a species of Rubiaceae growing in the forest (10 records), the Verbenaceae Stachytarpheta polyura (L.) (5 records) and Lantana camara L. (3 records). Only Aristolochia triangularis was observed as larval host plant in the study site. The behavior observed in ovipositing females and larvae was the same as reported in the literature (see Brown-Jr. et al., 1981).

\section{DISCUSSION}

Even if there are some good populational studies with species of Parides (Cook et al., 1971; Brown-Jr. et al., 1981, 1994; Brown-Jr., 1992; Tyler et al., 1994), there is little information about Parides anchises, especially in the coastal region. 
The population size of $P$. anchises nephalion in the present study peaked at tens of individuals. Considering that the adult sex ratio is 1:1 in most species (Tyler et al., 1994; Brown-Jr. et al.; 1994), the adult population size could be obtained by doubling the estimated number of males, giving a maximum possible of about 120 individuals, but usually 30 to 80 individuals. These values were near that obtained to several species of Parides throughout the neotropics, (Cook et al., 1971; Brown-Jr. et al., 1981, 1994; Tyler et al., 1994), with $P$. anchises reported as ocurring among the lowest population levels. Despite the low density of the adults, the observed pattern is very different from those reported to populations of Heliconius (Nymphalidae), that shows stable populations numbers throughout the year (Turner, 1971; Ehrlich \& Gilbert, 1973; Araujo, 1980; Rogner \& Freitas, 1999); and similar to those observed in populations of Ithomiinae, but with smaller population numbers (Vasconcellos-Neto, 1980; Freitas, 1993, 1996; Pinto \& Motta, 1997).

During the study period, the population growth occurred in the hottest and wettest month, and decrease in a unusual dry month (February 1997), but, unfortunately, seasonal patterns could not be discussed due to the short study period.

TABLE 1

Populational data for Parides anchises nephalion in the Morro do Voturuá. $\mathbf{M}+\mathbf{R}=$ marked plus recaptured; NIPD = number of individuals present per day; $\mathbf{N}=$ number estimated; $\mathbf{S E}=$ standard error; $\mathbf{L P}=$ Lincoln-Petersen-Bailey; JS = Joly-Seber, MP = Manly-Parr.

\begin{tabular}{|c|c|c|c|c|c|}
\hline Date & $\mathbf{M}+\mathbf{R}$ & NIPD & $\begin{array}{c}\mathbf{L P} \\
\mathbf{N} \pm \mathbf{S E}\end{array}$ & $\begin{array}{c}\text { JS } \\
\mathbf{N} \pm \mathbf{S E}\end{array}$ & $\begin{array}{c}\text { MP } \\
\mathbf{N} \pm \mathbf{S E}\end{array}$ \\
\hline 5 Aug & 3 & 3 & $12 \pm 14$ & - & - \\
\hline 17 Aug & 3 & 4 & $15 \pm 18$ & - & - \\
\hline 24 Aug & 4 & 5 & $12 \pm 13$ & - & - \\
\hline $4 \mathrm{Sep}$ & 2 & 3 & $12 \pm 15$ & $4 \pm 8$ & - \\
\hline 7 Sep & 5 & 5 & $10 \pm 8$ & $3 \pm 0$ & - \\
\hline $19 \mathrm{Sep}$ & 3 & 3 & $6 \pm 4$ & $2 \pm 2$ & $3 \pm 0$ \\
\hline $30 \mathrm{Sep}$ & 5 & 5 & $8 \pm 5$ & $4 \pm 0$ & $5 \pm 0$ \\
\hline 11 Oct & 4 & 4 & $20 \pm 24$ & - & - \\
\hline $18 \mathrm{Oct}$ & 4 & 4 & $12 \pm 13$ & - & - \\
\hline 24 Oct & 2 & 2 & $10 \pm 12$ & - & - \\
\hline $5 \mathrm{Nov}$ & 4 & 4 & $24 \pm 30$ & - & - \\
\hline $16 \mathrm{Nov}$ & 5 & 5 & $20 \pm 24$ & - & - \\
\hline $1 \mathrm{Dec}$ & 3 & 3 & $18 \pm 18$ & - & - \\
\hline $9 \mathrm{Dec}$ & 11 & 11 & $25 \pm 19$ & $10 \pm 0$ & $11 \pm 0$ \\
\hline $15 \mathrm{Dec}$ & 6 & 9 & $16 \pm 12$ & $17 \pm 23$ & $24 \pm 18$ \\
\hline $20 \mathrm{Dec}$ & 7 & 10 & $11 \pm 5$ & $16 \pm 16$ & $14 \pm 4$ \\
\hline $23 \mathrm{Dec}$ & 7 & 10 & $14 \pm 8$ & $15 \pm 15$ & $17 \pm 8$ \\
\hline $25 \mathrm{Dec}$ & 7 & 8 & $17 \pm 15$ & $8 \pm 8$ & $14 \pm 9$ \\
\hline $30 \mathrm{Dec}$ & 4 & 5 & $12 \pm 13$ & $8 \pm 12$ & - \\
\hline 7 Jan & 2 & 3 & $4 \pm 3$ & - & - \\
\hline 12 Jan & 1 & 2 & $5 \pm 6$ & $2 \pm 2$ & - \\
\hline $14 \mathrm{Jan}$ & 4 & 4 & $8 \pm 6$ & $2 \pm 0$ & - \\
\hline $21 \mathrm{Jan}$ & 3 & 3 & $3 \pm 0$ & $2 \pm 0$ & - \\
\hline 31 Jan & 1 & 1 & $2 \pm 1$ & - & - \\
\hline $3 \mathrm{Feb}$ & 1 & 1 & $2 \pm 1$ & - & - \\
\hline $6 \mathrm{Feb}$ & 1 & 1 & $2 \pm 1$ & - & - \\
\hline $14 \mathrm{Feb}$ & 1 & 1 & $3 \pm 3$ & - & - \\
\hline $17 \mathrm{Feb}$ & 2 & 2 & - & - & - \\
\hline
\end{tabular}


TABLE 2

Sex ratio and mean male forewing length (in $\mathrm{mm}$ ) (both based on monthly recruitment) of Parides anchises nephalion in this study. Asterisks indicates that the sex ratio was significantly different from 1:1 (chi-square tests, $\mathrm{p}<0.05) . \mathrm{m}=$ males; $\mathrm{f}=$ females, $\mathrm{MFL}=$ male forewing length, $\mathrm{N}=$ sample size.

\begin{tabular}{|l|c|c|c|c|}
\hline \multirow{2}{*}{ Month/year } & \multicolumn{2}{|c|}{ Sex ratio } & \multicolumn{2}{c|}{ Male forewing length } \\
\cline { 2 - 5 } & m:f & $(\%)$ & Mean \pm SD & N \\
\hline Aug/1996 & $10: 4$ & $71: 29$ & $43.0 \pm 3.74$ & 10 \\
\hline Sep/1996* & $10: 2$ & $83: 17$ & $41.8 \pm 4.52$ & 10 \\
\hline Oct/1996 & $8: 0$ & $100: 0$ & $41.6 \pm 3.16$ & 8 \\
\hline Nov/1996 & $9: 1$ & $90: 10$ & $43.8 \pm 2.68$ & 9 \\
\hline Dec/1996 & $28: 21$ & $57: 43$ & $41.8 \pm 4.06$ & 27 \\
\hline Jan/1997 & $7: 3$ & $70: 30$ & $42.1 \pm 4.26$ & 7 \\
\hline Feb/1997 & $5: 0$ & $100: 0$ & $41.2 \pm 1.26$ & 4 \\
\hline Total & $77: 31$ & $71: 29$ & $42.2 \pm 3.71$ & 75 \\
\hline
\end{tabular}

TABLE 3

Permanence of marked males of $P$. anchises nephalion in the Morro do Voturuá. Days elapsed between marking and last recapture represent the minimum permanence (MP) for each individual.

\begin{tabular}{|c|c|c|}
\hline MP & Males & $\mathbf{P}(\boldsymbol{\%})$ \\
\hline $1-6$ & 3 & 16.7 \\
\hline $7-12$ & 5 & 27.8 \\
\hline $13-18$ & 5 & 27.8 \\
\hline $19-24$ & 3 & 16.7 \\
\hline $25-30$ & 2 & 11.0 \\
\hline Total & 18 & 100.0 \\
\hline
\end{tabular}

The average time of residence and the life expectance agrees with those found in other species of Parides (Cook et al., 1971; Brown-Jr. et al., 1981, 1994; Tyler et al., 1994). Cook et al. (1971) found an life expectance of 5.7 days for $P$. neophilus, very near that obtained in the present study (5.6 days).

In general, the maximum permanence reported for most species of Parides was around 6 to 8 weeks in the field, except for $P$. anchises, $P$. ascanius and $P$. neophilus, all with maximum permanence values of around 2-4 weeks (Tyler et al., 1994, Brown-Jr. et al., 1994, this study). The average time of residence of Parides can be considered low if compared with those of other tropical mimetic butterflies such as Heliconiini (Turner, 1971; Benson, 1972; Ehrlich \& Gilbert, 1973; Araujo, 1980; Quintero, 1988; Ramos \&
Freitas, 1999), and Ithomiinae (VasconcellosNeto, 1980; Freitas, 1993, 1996; Table 5 in Ramos \& Freitas, 1999).

Brown-Jr. et al. (1981) cited the low lifespan of adults combined with weekly samples (resulting in low recapture rates) as the main reason for not using estimates in a study with Troidini in the Campinas region. Fuiture studies with populations of Troidini should consider this, and the population should be studied at intervals shorter than one week.

The male biased sex ratio was also recorded for some natural populations of Parides (about 2 males: 1 female according to Brown-Jr. et al., 1994), but reared lots typically results in a sex ratio of 1:1 (Tyler et al., 1994, Brown-Jr. et al., 1994).

Thus, like in most butterflies, male biased sex ratio could be a result of differences in the 
behavior of males and females, resulting in a higher catchability of males (Brussard \& Ehrlich 1970; Ehrlich \& Gilbert, 1973; Ehrlich, 1984; Ehrlich, et al., 1984; Freitas, 1993, 1996; Tyler et al., 1994; Ramos \& Freitas, 1999).

Even if species of Parides were good flyers and traveled distances of up to $55 \mathrm{~km}$ (BrownJr. et al., 1981, 1994), these values could vary according to the studied area. In $P$. anchises the maximum distances recorded varied from 140 to 1,500 m (Brown-Jr. et al., 1994), and in this particular the results obtained in the present work are in accord with those of previous studies.

Unfortunately, the average distances were not presented in these previously cited works, and the averages are probably a more representative parameter of the population than maximum values.

The use of flower resources by $P$. anchises nephalion in Morro do Voturuá is similar to that recorded in Monjolinho (a small forest fragment near Campinas, SP) (Brown-Jr. et al., 1981), where the most used species was also Impatiens, an introduced plant species.

In general, all features described to $P$. anchises nephalion in the present paper agree with those recorded for other species of Parides in the Neotropics. However, this information is important in understanding the ecology of $P$. anchises, which is one of the most widespread species of Parides, ranging from North Argentina to Panamá (see maps in Tyle et al., 1994), and occurring in several habitats and forest types. Some very widespread species could present differences in population features throughout their range (Ramos \& Freitas, 1999), and understanding of this ecological plasticity could helps in understanding the ecology of tropical insects.

Acknowledgments - We thank R. B. Francini and K. S. Brown Jr. for discussions and comments on the manuscript. R. B. Francini helped in field work and in population analysis. Climatological data were kindly provided by the Brazilian Air Force. A. V. L. Freitas thanks the CNPq for a fellowship.

\section{REFERENCES}

ARAUJO, A. M., 1980, Estudos genéticos e ecológicos em Heliconius erato (Lepidoptera, Nymphalidae). Actas IV Congr. Latinoam. Genética. 2: 199-206.

BENSON, W. W., 1972, Natural selection for müllerian mimicry in Heliconius erato in Costa Rica. Science, 176: 936-939.
BROWN-JR., K. S., 1992, Borboletas da Serra do Japi: Diversidade, hábitats, recursos alimentares e variação temporal, pp. 142-187. In: L. P. C. Morellato (ed.), História natural da Serra do Japi. Ecologia e preservação de uma área florestal no sudeste do Brasil. Editora da Unicamp/Fapesp, Campinas.

BROWN-JR., K. S., DAMMAN, A. J. \& FEENY, P. P., 1981, Troidine swallowtails (Lepidoptera: Papilionidae) in South-eastern Brazil: Natural history and foodplant relationships. J. Res. Lepid. 19: 199-226.

BROWN-JR., K. S., KLITZKE, C. F., BERLINGERI, C. \& RUBBO DOS SANTOS, P. E., 1994, Neotropical swallowtails: chemistry of foodplant relationships, population ecology, and biosystematics, pp. 405-445. In: J. M. Scriber, Y. Tsubaki \& R. C. Lederhouse (eds.), Swallowtail butterflies: Ecology and Evolutionary Biology. Scientific Publishers, Gainesville.

BRUSSARD, P. F. \& EHRLICH, P. R., 1970, The population structure of Erebia epipsodea (Lepidoptera: Satyrinae). Ecology 51: 119-129.

COOK, L. M., BROWER, L. P. \& CROZE, H. J., 1967, The accuracy of a population estimation from multiple recapture data. J. Anim. Ecol. 36: 57-60.

COOK, L. M., FRANK, K. \& BROWER, L. P., 1971, Experiments on the demography of tropical butterflies. I. Survival rate and density in two species of Parides. Biotropica 3: 17-20

DRUMMOND-III, B. A., 1976, Comparative Ecology and Mimetic Relationships of Ithomiine Butterflies in Eastern Ecuador. Ph.D. Thesis, University of Florida, Gainesville, USA, xvi + 361 pp.

EHRLICH, P. R., 1984, The structure and dynamics of butterfly populations, pp. 25-40. In: R. I. Vane-Wright \& P. R. Ackery (eds.), The Biology of Butterflies. Academic Press, London.

EHRLICH, P. R. \& DAVIDSON, S. E., 1960, Techniques for capture-recapture studies of Lepidoptera populations. $J$. Lepid. Soc. 14: 227-229.

EHRLICH, P. R. \& GILBERT, L. E., 1973, Population structure and dynamics of the tropical butterfly Heliconius ethilla. Biotropica 5: 69-82.

EHRLICH, P. R., LAUNER, A. E. \& MURPHY, D. D., 1984, Can sex ratio be defined or determined? The case of a population of checkerspot butterflies. Am. Nat. 124: 527539

FREITAS, A. V. L., 1993, Biology and population dynamics of Placidula euryanassa, a relict ithomiine butterfly (Nymphalidae: Ithomiinae). J. Lepid. Soc. 47: 87-105.

FREITAS, A. V. L., 1996, Population biology of Heterosais edessa (Nymphalidae) and its associated Atlantic Forest Ithomiinae community. J. Lepid. Soc. 50: 273-289.

HABER, W., 1978, Evolutionary Ecology of Tropical Mimetic Butterflies (Lepidoptera: Ithomiinae). Ph.D. Dissertation, Univ. of Minnesota USA, xii + 227 pp.

MORAIS, A. B. B. \& BROWN-JR., K. S., 1992, Larval foodplant and other effects on Troidini guild composition (Papilionidae) in southeastern Brazil. J. Res. Lepid. 30: 19-37. 
NIMER, E., 1972, Climatologia da Região sudeste do Brasil. Introdução à climatologia dinâmica. Rev. Bras. Geogr. 34: 3-48.

PINTO, A. S. \& MOTTA, P. C., 1997, Dinâmica populacional de um grupo de borboletas transparentes (Lepidoptera: Nymphalidae: Ithomiinae). In: L. Leite \& C. H. Saito (orgs.), Contribuição ao Conhecimento Ecológico do Cerrado - Trabalhos Selecionados do 30 Congresso de Ecologia do Brasil (Brasília, 6-11/10/96), Departamento de Ecologia, Universidade de Brasília, Brasília.

PRODESAN, 1969, Estudo da Viabilidade do Distrito Industrial de Santos. $91 \mathrm{pp}$

QUINTERO, H. E., 1988, Population Dynamics of the butterfly Heliconius charitonius L. In Puerto Rico, Caribb. J. Sci. 24: 155-160.

RAMOS, R. R. \& FREITAS, A. V. L., 1999, Population biology, wing color variation and ecological plasticity in Heliconius erato phyllis (Nymphalidae). J. Lepid. Soc. 53: 11-21.

SANTOS, E. O., 1965, Características climáticas, pp. 95-150. In: A Baixada Santista. Aspectos Geográficos. Vol. 1, Cap. 4. As Bases Físicas. Editora da Universidade de São Paulo.

SCHAPPERT, P. J. \& SHORE, J. S., 1998, Ecology, population biology and mortality of Euptoieta hegesia Cramer (Nymphalidae) on Jamaica. J. Lepid. Soc. 52: 9-39.

SETZER, J., 1949, Contribuição Para o Estudo do Clima do Estado de São Paulo. Edit. Escolas Profissionais Salesianas, São Paulo. 239 pp.
SOUTHWOOD, T. R. E., 1971, Ecological Methods with Particular Reference to the Study of Insect Populations. Chapman \& Hall, London, 524p.

TRIGO, J. R., 1988, Ecologia química na interação Ithomiinae (Lepidoptera: Nymphalidae)/Echitoideae (Angiospermae: Apocynaceae). M.S. Thesis, Universidade Estadual de Campinas, Campinas, SP, xiv + 199p.

TURNER, J. R. G., 1971, Experiments on the demography of tropical butterflies. II. Longevity and home range behavior in Heliconius erato. Biotropica 3: 21-31.

TYLER, H. A., BROWN-JR., K. S. \& WILSON, K. H., 1994, Swallowtail Butterflies of the Americas. A Study in Biological Dynamics, Ecological Diversity, Biossystematics and Conservation. Scientific Publ., Gainesville, 376p.

URURAHY, J. C., COLLARES, J. E. R., SANTOS, M. M. \& BARRETO, R. A. A., 1987, Vegetação. In: Projeto RADAMBRASIL. Vol. 32 pp.23-24 (Rio de Janeiro e Vitória). Ed. Ministério das Minas e Energia, Brasília, DF.

VASCONCELLOS-NETO, J., 1980, Dinâmica de Populações de Ithomiinae (Lepidoptera: Nymphalidae) em Sumaré, SP. M.S. Thesis, Universidade Estadual de Campinas, Campinas, SP. vi $+206 \mathrm{p}$.

WALTER, H., 1985, Vegetation of the Earth. Springer-Verlag, Berlin, Germany.

YOUNG. A. M. \& MOFFETT, M. W., 1979, Studies on the population biology of the tropical butterfly Mechanitis isthmia in Costa Rica. Amer. Midl. Nat. 101: 309-319. 